\title{
Original Article \\ The Middle Income Trap: A Case Study of Korea and Lesson for Vietnam
}

\author{
Nguyen Minh Trang* \\ Diplomatic Academy of Vietnam, 69 Chua Lang, Dong Da, Hanoi, Vietnam \\ Received 03 June 2020 \\ Revised 4 November 2020; Accepted 26 November 2020
}

\begin{abstract}
In the 20th century, Asia was not only famous for war, poverty and backwardness but also for the emerging of Asian dragons like South Korea, Taiwan, Hong Kong and Singapore. These economies have successfully escaped from the middle income group to join high income economies with amazing growth rate. In 2008, Vietnam officially entered the group of middle-income countries, escaping from poverty and underdevelopment with rapidly increasing average income. However, the signs of "middle income trap" have also emerged. Among the four Asian dragons, South Korea has many similarities with Vietnam, such as devastation by war, low-income and poor resources, strong dependence on foreign aid and especially the separation between the North and the South. After the Korean War (1950-1953), South Korea was one of the poorest countries in the world. However, over the past nearly four decades, South Korea has demonstrated incredible growth and global integration and become a high - tech industrialized economy. By analysing the South Korean policies, Vietnam can learn from their success and failure to overcome the middle-income level that has trapped it for almost 10 years with a focus on improving Government's role, capital control, human resource and technology.
\end{abstract}

Keywords: Middle income trap, Vietnam, South Korea.

\section{Introduction}

Currently, international organizations classify countries according to different criteria, including the criterion of per capita income. The World Bank distinguishes the income based on

\footnotetext{
* Corresponding author.

Email address: trangdav@gmail.com
}

https://doi.org/10.25073/2588-1116/vnupam.4240 the measure of prosperity, including: the poverty rate, infant mortality rate, and per capita income. Accordingly, countries are divided into four income groups: i) Low-income countries are those with per capita income of USD 1,025 or 
less; ii) Lower-middle-income countries are those with per capita income between USD 1,026 and USD 4,035; iii) Upper-middle-income countries are those with per capita income between USD 4,036 and USD 12,475; and iv) High-income countries are those with per capita income of USD 12,476 or more. According to this classification, there are 31 low-income countries, 52 lower-middle-income countries, 56 upper-middle-income countries and 78 highincome countries in the world. Vietnam belongs to the group of lower-middle-income countries with the GDP per capita is $\$ 2.590$ in 2018 [1].

The United Nations (UN) also assigns the world's economy into four income groups: Lowincome countries have a per capita income of less than USD 765; Lower-middle-income countries have a per capita from USD 765 to USD 3,000; Upper-middle-income countries have a per capita from USD 3,000 to USD 9,100; High-income countries have a per capita of more than USD 9,100 (this level varies according to the global economic situation and the current price of the low - income level is USD 875 per year [1].

The "middle-income trap", in general terms, is an economic development situation in which a middle-income country has been unable to transit to a high-income country in a certain number of years and potentially into the future. The concept of "middle income trap" indicates the economic downturns occurring in developing countries in East Asia, which after a period of rapid growth have reached middle income levels, cannot become high income countries for decades. Then, the rate of economic growth is declining. Thus, getting rid of the middle income trap is important for countries on the path of development. According to the World Bank, the middle-income trap occurs when a country that has been stuck for 42 years does not overcome the basic per capita income of $\$ 4,000$ $\$ 6,000 /$ year, which the country gained thanks to the resources and certain early advantages (only luck without effort). Countries that fall into the middle-income trap tend to have low rates of investment, slow-growing manufacturing, less diversified industries and less active labor markets. Certainly, many developing countries have enjoyed the benefits of transitioning, some rapidly, from a low-income country to a middleincome country, but out of 101 middle-income countries, only 13 countries have seemed to manage to escape the middle-income trap. These countries and regions are Equatorial Guinea, Greece, Hong Kong, Ireland, Israel, Japan, Mauritius, Portugal, Puerto Rico, South Korea, Singapore, Spain, and Taiwan [2]. This is a sad situation, where the growth of a country simply stagnates or even decreases, ensuring the country's economy will remain in the middle-income level for a very long time and has little hope of seeing it reach high-income in the close future.

After World War II, many countries and very notably, the Asian Tigers developed rapidly to turn into middle-income countries. In a general term, the factors that led the escape from being a low-income country were according to the World Bank, "low-cost labor and easy technology adoption". These important factors however no longer contributed to the aforementioned rapid growth once the countries left their low-income status for middle-income status. Instead, the countries had to find other sources of growth, mainly, as the World Bank argues, through innovation. Other researchers have also pointed out several factors why countries remain stuck in a middle-income trap. Chang-yong Rhee from the ADB claims that countries that are stuck have the following characteristics: "low investment ratios, slow manufacturing growth, limited industrial diversification and poor labor market conditions". Ejaz Ghani also states two factors to which middle-income countries "cling too long to past successful policies" or they "exit prematurely from the industries that could have served as the basis for their specialization process". Some of these factors are interconnected and the lack of industrialization and productivity as mentioned earlier are certainly outcomes of these aforementioned reasons [3]. 
The process of falling into the "middle income trap" of the economy seems to be a necessity, and any country starting with an economy based on the exploitation of available resources, exports of monoculture products, selfsufficiency agriculture and expectation of aid, needs to industrialize for development. The process of the catch up industrialization described by Professor Kenichi Ohno (National Graduate Institute for Policy Studies) includes four stages [4]:

- Stage 1: begin with the mass appearance of foreign direct investment (FDI) manufacturing companies, undertake simple assembly or process the light industrial products for exports such as textiles, footwear, food,... In this stage, all activities such as design, technology, production and marketing are led by foreigners, the main materials and spare parts are imported while the recipient country only contributes simple labor source and industrial land. That leads to a very small internal level, overwhelmed by the value created by foreigners despite of the fact that employment and income for the poor get improved.

- Stage 2: as the amount of FDI is accumulated and the scale of production is expanded, the domestic supply of spare parts and components begins to increase. This is partly due to FDI providers investing in and partly due to the appearance of local suppliers. The assembly companies become more competitive and the linkage between the assembly company and the supplier starts to appear. This industry is growing strongly in volume due to the increased supply of domestic inputs. Manufacturing is still under the management and guidance of foreigners so the value of the increase is not much. Obviously, wages and incomes in the country are the same.

- Stage 3: this is the stage of internal skills and knowledge through human capital accumulation in the industry. Domestic workers must replace foreign workers in all areas of production including management, technology, design, factory operation, logistics, quality management and marketing. Because of the decreasing dependence on foreigners, the intrinsic value has increased dramatically. The country has become an exporter of high quality manufactured products, challenging its predecessors and re-establishing itself in the global industrial market.

- Stage 4: the country has the capacity to create new products and lead the global market trend. Among the four above-named stages, Kenichi Ohno said that with the available natural resources, geography, and so on, each country could reach the lower middle income level from Stage 1 and grows to the upper-middle income level in Stage 2. When stepping into Stage 3, they will reach high income. There is nothing to say if every country goes through those stages smoothly. But the fact is that many countries, after crossing the low-income threshold, grow slower and are stuck there for several decades. They become a victim of the "middle income trap".

Starting at a very low level, Vietnam is currently in the early stage of industrialization and is trying to advance to Stage 2. In South East Asia, many countries such as Indonesia, Malaysia and Thailand have been stuck in the middle income trap for years though they are at higher level of development than Vietnam. In this context, there is a great concern that Vietnam will be in the same situation. Thus, it is necessary for Vietnam to find out solutions to overcome the middle income trap and pursue sustainable development. South Korea has many similarities with Vietnam and has successfully become a developed nation after few decades. Vietnam can learn from their policies and practice to shorten the way to become a developed country.

\section{South Korea Middle Income Trap}

After the Korean War (1950-1953), Korea was one of the poorest countries in the world, having many similarities with other underdeveloped countries such as: devastation by war, low income, poor natural resources, strong dependence on foreign aid and especially, the separation between the North and South. Even after the post-war reconstruction period (1953-1960), Korea's per capita income was only 
of 80 USD (1960). South Korea's “economic miracle" began under the military government of General Park Chung Hee, who came to power in a coup in May 1961. Several steps were taken during this period to direct the state toward economic growth through 7 five-year economic plans, which brought certain achievements for the economy. Particularly from after 1963, Korea has risen strongly, quickly standing on par with the rich countries in the world. Specifically,
Korea with a low average income level in 1969, achieved a high average income level in 1988 and reached the threshold of high-income countries in 1995. Thus, in just over three decades, Korea has achieved a miraculous leap, prompting the country to quickly escape the middle income trap. South Korea's income per capita increased more significantly since 1985 with the Fifth Five-year Economic Plan.

Table 1. The five-year economic plans of South Korea (1962-1995)

\begin{tabular}{|c|c|c|}
\hline Plans & Content & Detail policies \\
\hline $\begin{array}{l}\text { First Five-Year } \\
\text { Plan (1962-1966) }\end{array}$ & $\begin{array}{l}\text { - Concentrate on the textile } \\
\text { industry and make South Korea } \\
\text { self-sufficient. }\end{array}$ & $\begin{array}{l}\text { - Nationalize all commercial banks and allow the } \\
\text { banking system control over credit; } \\
\text { - Provide low interest loans to business; } \\
\text { - Encourage the development of light industries } \\
\text { for export. }\end{array}$ \\
\hline $\begin{array}{l}\text { Second Five-Year } \\
\text { Plan (1967-1971) }\end{array}$ & $\begin{array}{l}\text { - Shift to the heavy industry; } \\
\text { - Attract FDI and improve the } \\
\text { basic infrastructure. }\end{array}$ & $\begin{array}{l}\text { - Modernize the industrial structure and develop } \\
\text { substitute industries, including steel, machinery } \\
\text { and chemical industries. }\end{array}$ \\
\hline $\begin{array}{l}\text { Third Five-Year } \\
\text { Plan (1972-1976) }\end{array}$ & $\begin{array}{l}\text { - Follow export-orientation; } \\
\text { - Focus on less developed areas; } \\
\text { - Implementation of the Heavy } \\
\text { Chemical Industrialization Plan } \\
\text { (HCI Plan). }\end{array}$ & $\begin{array}{l}\text { - Promote heavy and chemical industries } \\
\text { including: iron and steel, transports machinery, } \\
\text { household electronic, shipbuilding and } \\
\text { petrochemicals; } \\
\text { - Supply new industries with raw materials and } \\
\text { capital goods; } \\
\text { - Construct new industries in the southern part of } \\
\text { the peninsula. }\end{array}$ \\
\hline $\begin{array}{l}\text { Fourth Five-Year } \\
\text { Plan (1977-1981) }\end{array}$ & $\begin{array}{l}\text { - Developed competitive } \\
\text { industries in the world's industrial } \\
\text { export markets. }\end{array}$ & $\begin{array}{l}\text { - Focus on technology-intensive and skilled labor- } \\
\text { intensive industries such as: machinery, } \\
\text { electronics and shipbuilding; } \\
\text { - Focus on large heavy and chemical industries } \\
\text { (iron, steel, petrochemicals and nonferrous metal. }\end{array}$ \\
\hline $\begin{array}{l}\text { Fifth Five-Year } \\
\text { Plan (1982-1986) }\end{array}$ & $\begin{array}{l}\text { - Change from heavy and chemical } \\
\text { industries to technology-intensive } \\
\text { industries. }\end{array}$ & $\begin{array}{l}\text { - Make high-technology products (precision } \\
\text { machinery, televisions..., and information). }\end{array}$ \\
\hline $\begin{array}{l}\text { Sixth Five-Year } \\
\text { Plan (1987-1991) }\end{array}$ & $\begin{array}{l}\text { - Shift to technology-intensive } \\
\text { industries. }\end{array}$ & $\begin{array}{l}\text { - Accelerate import liberalization; } \\
\text { - Remove restrictions and non-tariff barriers on } \\
\text { imports. }\end{array}$ \\
\hline $\begin{array}{l}\text { Seventh Five-Year } \\
\text { Plan (1992-1995) }\end{array}$ & $\begin{array}{l}\text { - Develop new high-technology } \\
\text { fields such as microelectronics, } \\
\text { new materials, fine chemicals, } \\
\text { bioengineering, optics and } \\
\text { aerospace. }\end{array}$ & $\begin{array}{l}\text { - Government and industry work together to build } \\
\text { high-technology facilities in seven provincial } \\
\text { cities to better balance the geographic distribution } \\
\text { of industry throughout South Korea. }\end{array}$ \\
\hline
\end{tabular}




\section{Policies Analysis}

\subsection{Efficient and Flexible Intervention of Government}

In the case of Korea, one of the most important factors helping the country escape its successful middle income trap is the flexible, consistent and effective regulatory role of the government. The government continually adjusted economic goals to adapt to the shift in economic structure as well as the increase in income and changes in prioritized economic issues. This is clearly reflected in the Korean government's five-year economic plans. From 1961 to 1996, there were 7 five-year plans implemented with different orientations. The above plans, although indicative and oriented mainly, play a role in regulating the economy quite strongly. The Korean government is known to be a fairly successful government in combining a flexible market and plan. When the market has not been able to self-operate to achieve its goals, the government will apply strong interventions to ensure its planned objectives. On the contrary, when the market can operate effectively, the government will reduce its intervention, even by privatizing state units.

Another outstanding feature of the Korean government's operating economy in the period 1962-1996 is expressed in the following basic philosophy: economic development is achieved through industrialization and being controlled and led by the government. The government uses direct intervention policies such as price controls, direct investments in specific industries such as steel and financial support to promote priority industries. Creating jobs, paying foreign debts and promoting exports are identified as the first priority issues in economic policies. Growth targets are more important than solving the balance of income distribution as well as the imbalance in industrial development among regions. Because they think it is due to growth, these problems will then be overcome. In other words, growth goes ahead, fairness follows. Thanks to the thorough application of the above philosophy, the Korean Government has achieved most of the goals set out in economic development plans.

In addition to the above characteristics, Korea's brilliant economic development is thanks to the right decisions of the Korean Government, typically the government of President Park Chung Hee (1961-1979) when choosing and pursuing the same strategy of outward export based on industrial exports or export-oriented industrialization strategies. Through this strategy, Korea can simultaneously promote three goals: modernization, industrialization and internationalization. Obviously, as a poor country in terms of resources, limited in the domestic market, lack of capital and technology, Korea cannot implement its development strategy towards exploiting natural resources or replacing imports. In addition, due to the need to import food and other materials, Korea is forced to export manufactured goods to collect foreign exchange. President Park's maxim "export first" is considered a guideline for Korea's economic activities later on. Consistency in Korean government policy making is also reflected in the goal of improving international competitiveness. From the beginning of 1965, President Park mentioned global competitiveness, which emphasized that competition with other countries in the export sector is not an option but a must. Since the early days of the export-oriented strategy, the government has aimed to strengthen Korea's international competitive position. Over the past five decades, the implementation of this goal has been maintained.

In general, Korea's economic development achievements have a great contribution from the government. This key role is expressed in many economic decisions, not only in development strategies or economic plans, but also in a variety of other policies.

\subsection{Self-motivated Industrialization Policy}

For Korea, industrial policy is at the heart of development policies, helping the country to restructure its economy towards industrialization 
and modernization. The government has made strong protection for industries since its early days of development. All monetary and financial policy instruments are used to support key industries such as cement, fertilizer or petrochemical industry.

In the period 1950-1960, Korea's industrial policy was characterized by an import substitution policy that focused mainly on consumer goods. The government fully utilizes tariff barriers and import restrictions to the maximum in order to protect domestic industries and promote domestic production. This strategy, despite promoting South Korea's autonomy and independence, reduced its dependence on the outside, but did not bring much effect. Average GDP growth from 1953 to 1962 was only $3.7 \%$.

In the early 1960s, import substitution strategies proved to be more disadvantageous, Korea's international competitiveness was also weakened in the sectors where it had a comparative advantage. In addition, due to increased demand for imported food and input materials while foreign aid plummeted, Korea was forced to export manufactured goods to collect foreign exchange. Under these circumstances, Korea's industrial policy had to be changed. In 1964, export-oriented policy was born with the slogan "export is first". Since then, the government has focused all efforts to boost exports, considering exports to be a national issue. The government increased direct subsidies to export industries, especially labor-intensive light industries such as textiles, yarns and footwear - which are Korean industries that have a competitive advantage. By the mid-1960s, the government introduced measures to promote exports such as tax exemption, reduction and financial support. In addition to the above measures, the government also provided the necessary infrastructure for economic development, such as building complex industrial parks and encouraging firms to join these complexes. The Government also established organizations to promote exports such as: Korea Trade and Investment Promotion
Agency (KOTRA) and Korea International Trade Association (KITA).

Entering the 1970s, Korea's industrial policy shifted from light industries to developing heavy and chemical industries with high added value. The government recognizes that if they continue to develop light industries, rising wages will reduce the price competitiveness of laborintensive industries. Therefore, in 1973, the government issued a plan to develop heavy industry and chemicals. Accordingly, the government selected six strategic industries, including: steel, shipbuilding, machine tools, electronics, metal, and petrochemical. This choice is based on standards such as forward and reverse linkages between sectors, contributing to economic growth and exchange rate gains. Attached to this policy is the rise of large industrial corporations. The government promotes the development of HCI sectors through policies such as providing concessional loans, selective protection, input regulations and tax exemptions and reductions, among others. Therefrom, the proportion of heavy industries in Korea increased rapidly from $38 \%$ in 1973 to $54.4 \%$ in 1980 and accounted for $50 \%$ of total export value in 1980. It can be said that Korea's fast economy growth in the 1960s and 1970s was largely thanks to the increase of exports [5].

In the 1980s and 1990s, the economy began to show stagnation due to the effects of the oil and economic crisis of 1973-1975, causing an imbalance in the industrial structure and reducing competitiveness. Therefore, the Korean Government was forced to make adjustments to industrial policy towards increasing market liberalization, giving more autonomy to the private sector and developing high-tech industries such as semiconductor industry, automobile, shipbuilding, aviation. Thanks to the focus on investment in science and technology in this period, Korea made a big breakthrough, quickly becoming a high-income country. Korea's industrial policy made a reasonable transition from light industry to heavy industry, and then shifted to high-tech industry, based on available economic potential 
and context of the world economy in each period. Korea also showed its wisdom to implement an export-oriented industrialization strategy very early on and gave absolute priority to developing these industries.

\subsection{High-qualified Human Resources}

Another reason for the strong economic development is that Korea has a good education and a qualified workforce. Starting from a resource-poor country, Korea has nothing but abundant human resources. Taking advantage of this with the nation's tradition of fondness for learning, from the beginning, the Korean Government appreciated the role of education, considering education as a top strategic priority, a foundation for building the country.

Since before the economy took off, education in Korea has been quite respected. Thanks to the enforcement of compulsory education law in 1948, the enrollment rate at all levels has increased rapidly in 1945-1961. As of 1960 , about $56 \%$ of the adult population in Korea had access to primary education and $20 \%$ achieved secondary education, much higher than in most other developing countries at that time (26\% and 5\%, respectively). As a result, the workforce in Korea underwent basic training early on. Later, despite being severely affected by the war, the role of education was not neglected. Since the 1960s, Korea's education policy has been constantly changing in order to achieve the objectives set out in economic plans and meet the changing needs of the market. In the early stages of economic development, the Korean Government places much interest in lower secondary education to provide a suitable and timely workforce for large-scale manufacturing in manufacturing industries. However, since the early 1980s, the government has focused its attention on developing higher education and higher education with the aim of creating a high-quality workforce to meet the needs of high-tech industry development. This is evident in the Korean government's spending on education. According to the Korea Institute for Educational Development, the proportion of public spending on higher education in GDP increased from $1 \%$ in 1970 to $1.9 \%$ in 2000. Meanwhile, the spending on primary and secondary education dropped from $4.3 \%$ to $3.9 \%$, respectively, in the same period [6].

Thanks to the investment in education, Korea has achieved many great achievements. As early as 1970 , the primary enrollment rate reached $100 \%$. Illiteracy rate fell from over $10 \%$ in 1970 to almost zero in 1997. High school enrollment rate reached $40 \%$ in 1970 and was almost universal in 1997. As for general education, Korea is ranked third among OECD countries in terms of qualification, and up to $84 \%$ of high school graduates entered universities and colleges in 1998. Thus, Korea's education can be seen developed quite quickly. This helps increase the capacity and qualifications of workers, enabling them to absorb technological advances and timely meet the needs of the economy. It is shown that the level of workers by education level in Korea increased significantly in the period 1960-1995. By 1995, this rate had nearly caught up with advanced countries, like Japan and America.

A highly qualified workforce is a major factor leading to rapid labor productivity growth in Korea. If in the mid-1970s, Korea only reached about $40 \%$ of labor productivity compared to that in Japanese manufacturing and $20 \%$ in the US; then by 1996 , Korea's labor productivity had reached $70 \%$ of Japan and nearly $50 \%$ of the US. This is due to the rapid increase in labor productivity of Korea in the 1980s and 1990s (8\% and 10\%, respectively); while in Japan and the US, the figure is only $6 \%$ and 3\%, respectively [7].

A major feature of South Korea's economic development was its focus on acquiring technical skills. The state created a number of centers to promote research and dissemination of technical knowledge to business enterprises such as Korean Institute of Science and Technology (KIST), established in 1966. It also promoted technical education by expanding the number of vocational secondary schools and two-year technical colleges as well as encouraged students 
to study abroad. At the same time, the Park administration made impressive progress in professionalizing the state bureaucracy. Officials received appointment through a highly competitive civil service examination system and were promoted based on clear guidelines for merit. Attracted by good pay and benefits, job security, and enhanced prestige, many of the country's top university graduates as well as those with overseas degrees entered the ranks of the bureaucracy. As a result, a highly competent, respected set of officials were able to help guide and promote economic and social development.

3.4. Focus on Developing Science and Technology and Constant Innovation

In Korea, the role of science and technology has been noticed since the early 1960s. Along with the advent of the first economic development plan is the first five-year plan to promote technology. Over time, the Korean Government made policy adjustments to suit the development stages of the economy. Specifically, the government focused on building infrastructure for technology development in the early stages of industrialization and shifting to developing key technologies later on.

In the early 1960s, two agencies were established, including a research institute of the Korea Institute of Science and Technology (KIST) (1966) and the Ministry of Science and Technology (MOST) (1967) that paved the way for public scientific and technological development in Korea. The main strategy of this period is to increase the import of foreign technology, build technical infrastructure and promote education and training. In the 1970s, the development of science and technology was still limited because the technology for laborintensive export industries as well as heavy industries and chemicals could easily be obtained from abroad. In general, in the early period, Korea's science and technology policy mainly focused on the introduction, acquisition and application of foreign technology. Since the 1980s, new science and technology policies have changed significantly, aiming to improve national scientific and technological capacities through promoting research and development (R\&D) activities. In 1982, the national R\&D program was born. Since then, science and technology activities in Korea began to flourish. This is reflected in data on $R \& D$ spending. $R \& D$ spending increased from only $0.25 \%$ of GDP in 1963 to $1.74 \%$ in 1991 and continued to increase in the following years. By 1996, R\&D spending accounted for $2.26 \%$ of GDP, higher than the average of OECD countries $(2.01 \%)$. With proper investment in science and technology, the efficiency of the Korean economy has increased. We can see that the total factor productivity (TFP) contributes greatly to economic growth during the period 1982-1995 (44\%) - a significant increase compared to $6 \%$ in the 1970 1982 period [8]. In short, Korea has shown the right early investment in science and technology development by a time when input factors such as labor and capital were no longer a comparative advantage of the country. In addition, the scientific and technical progress or the total factor productivity will be the factors contributing to the promotion of sustainable growth.

\section{Lessons for Vietnam}

Being Asian countries, Vietnam and South Korea share a number of things in common. Both Vietnam and Korea are rather small, situated on peninsulas (the Indochina peninsula and the Korean peninsula, respectively), with $2 / 3$ of the territories are mountainous areas and long sea coasts. With the similarities in geography, the climate conditions in Vietnam are the same as the ones in South Korea with 4 seasons: spring, summer, autumn and winter. Vietnam and South Korea are at the very important strategic locations and surrounded by big powers. This would influence their history and culture.

The most outstanding different feature between Vietnam and South Korea is political regime. After the war, Vietnam with the support from the Soviet Union follows socialist regime 
and is only led by the Communist Party of Vietnam. Meanwhile, there are 7 big parties and 13 small ones in Republic of Korea. This difference is one of the main cause of policy decision as well as economic growth direction from government. In terms of geography, with the area of $331.698 \mathrm{~km} 2$, a quarter of Vietnam's territory is plain with two large plains: Red River Delta and Mekong River Delta. In contrast, South Korea hardly has plain, mainly with lowland. That explains why Vietnam can well develop agriculture and is a leading rice exporting country.

There is also a difference in workforce of two countries when being middle-income ones. In 1969, when South Korea started reaching lower-middle-income level, it had young population and stable workforce with the advantage of abundant cheap labor for the future. Nevertheless, on being upper-middle-income country, South Korea had to face population aging. The working-age population is high but in 30 years without an effective measure, the population will be aging; whereas Vietnamese population, though pretty old, is not as worrying as that of South Korea because the percentage of people under working-age is still high with quite large population at the age of 30-40.

\subsection{Enhancing the Role of the Government}

Growth is not just about economics, it requires a competent, trustworthy and dedicated government. However, how much government intervention in the economy has so far remained the most paper-intensive question and not the same in each country. Some researchers argue that the government should intervene as little as possible and support the notion of "a smaller government and a more free market." According to Arthur Lewis, the government fail because they intervene too little or they may intervene too much. After more than 30 years of management reform, Vietnam has basically shifted from a bureaucratic, centrally-planned economy to a socialist-oriented market economy. The recognition and diversification of forms of ownership, and the economic components associated with the diversification of various types of business organizations are two major reasons for the economy to develop and reap the significant achievements. Basic types of markets have emerged and developed step by step in the whole country, linking with the regional and world markets, creating conditions for exploiting the potentials and advantages of each region and the whole country, developing production and circulating goods. Vietnam's economy operates according to the market economy under the management of the State through laws, policies, strategies, planning and other macro - regulatory instruments.

However, the process of improving market economy institutions in Vietnam still faces many obstacles in terms of awareness and implementation of policies. Specifically, there has been no consensus on ownership up to now, or defining the role of economic sectors, including state-owned enterprises (which are still considered to play the dominant role in the economy), alongside with low-efficiency businesses, strong state intervention in the markets, corruption, among others. As a result, incompleted economic institutions will also be one of the obstacles to the economic development of Vietnam.

The case of Korea shows the important role of the government in the success of the economy. It can be said that the Korean Government has given very appropriate, proper and timely policies. The lesson is that governments should have a long-term vision, set clear goals and pursue them. The policies introduced must be carefully considered based on the available capacity or comparative advantage of the country and adjusted accordingly to each stage of economic development as well as the international economic context. When realizing inadequacies and failures, the government needs to draw lessons and quickly make the necessary transition. The role of the government should not overwhelm or completely replace the market but needs to supplement and facilitate the operation of the market, keeps away from direct intervention in the early stages of development towards self-liberalization and then completes 
liberalization. In addition to the above factors, the government needs to ensure stable macroeconomics, social justice, good connection with the private sector and facilitate business activities. In short, to successfully overcome the middle income trap, the prerequisite is that the country needs a competent, long-term and determined government.

\subsection{Choosing Suitable Industrial and Agricultural Development Policy}

The key to achieving Vietnam's growth over the last few years is the exploitation of resources and the use of cheap labor. Vietnam's export earnings are mainly derived from the production of raw materials in mining and agro-forestry. The 15 key export items are in these two groups. Vietnam's current income is based on more than $70 \%$ of its resources, including crude oil, coal, minerals, timber, rice, seafood, rubber and coffee. What Vietnam needs to realize is that with the achievement of average income levels, inequalities in society have also risen to a very high level. In addition, some real estate traders, stock traders are rich but do not create many jobs for the society. Environmental pollution is occurring very seriously from rivers to ponds, lakes; forest destruction is increasingly serious, exhausting the source water; floods and droughts are more and more severe. Therefore, despite the worthy achievements, Vietnam needs to see all the limitations, shortcomings, deficiencies to overcome.

Obviously, export-oriented industrial policy has proved quite effective in promoting economic growth not only in the case of Korea but also in many other countries. It is noteworthy that Korea has pursued this policy since the early years of development and structural transformation is quite reasonable when moving from light industry to heavy industry and then towards developing industries with high-tech content; in other words, going from developing in width to developing in depth. The Korean government also showed their ability to select and focus resources to promote spearhead industries and policy redirects in time when recognizing the shortcomings in the development process. Thanks to detail policies focusing on technology-intensive industries carried out in the sixth and seventh five-year plans, South Korea's economy grew considerably from 1986 to 1995.

Unlike South Korea, from past to present, Vietnam with favorable terrain and climate is known as an agricultural country. Therefore, it is considerable for the authority to encourage enterprises joining the supply chain to reduce cost for all stages of the production and business process. More Vietnamese businesses need to invest in agriculture. It is also necessary that these businesses in the industry have a large scale to be able to compete with a competitive market consisting of many giant foreign enterprises.

Vietnam should make the most of domestic comparative advantages to carry out industrialization towards increasing quality and decreasing in quantity. Vietnam should carefully consider and research when selecting key industries based on standards such as forward and reverse linkages between sectors, contributing to economic growth, opportunity costs, and international context to suit each stage of development. Industrial policy should also be planned in the long term so that there can be better preparation of capital, human resources and infrastructure. In addition to developing industry, the government, particularly the Ministry of Agriculture and Rural Development, should formulate policy to develop advanced agriculture.

Along with that, the ministry should cooperate with enterprises to plan output products for the whole industry strategically in each period, in order to minimize the imbalance between supply and demand. It is not uncommon for heartbreaking scenes such as dragon fruits and watermelons to lose their crops, causing the price to escalate. On the contrary, when there are good crops, supply almost always surpasses demand, leading to a disastrous price drop. Therefore, ensuring stable output of products, balancing supply and demand, will help solve the problem of price stabilization, avoid speculation, and above all, avoid waste of effort 
and wealth of the whole society. Moreover, the state and businesses need to regulate and manage the effectiveness of the industry, particularly for individual farmers. In addition to the usual agricultural extension policies such as subsidies, seed grants, capital grants, or tax reductions, policies related to process management, quality control, hygiene and safety, and output assurance also need to be considered for application. As a result, farmers are not only contracted, but also supported, managed and inspected throughout the operation of the integrated value chain to ensure that the products are of good quality and fully consumed.

\subsection{Improve Human Resources Qualification, Science and Technology}

Although Vietnam's labor productivity increased continuously from 1986 to present with an everage yearly increase by $4.67 \%$ in the period $1986-2010$ and by $5.53 \%$ in the period 2001-2010, in absolute terms, labor productivity in Vietnam is still low compared to other countries [9]. Specifically, in 2010, Vietnam's overall labor productivity per year reached about $\$ 1,800$ per worker, much lower than the world average of over $\$ 14.6$ thousand/worker. Or, comparing the production in the manufacturing sector, while the productivity of the US is 100 , that of Vietnam is just 2.4, of India - 4.3, of Indonesia - 5.2, China - 6.9, Thailand - 7, Malaysia - 15.1, Singapore - 55.3 and South Korea - 63.6 [10]. Especially, the labour productivity of Vietnam has fluctuated strongly since 2011 and dropped by $8.23 \%$ in 2019 , which seriouly affected the development of all sectors [11].

Besides, the technological level of organizations, including enterprises in Vietnam, is far from the technological level of most countries in the world, typically in sectors such as textiles and garments, food processing, mechanics and the application of information technology to organizations. According to the Asia Foundation and Central Institute for Economic Management (2011), the technology level of most garment exporters is average, although many enterprises actively invest in new equipment; only a few enterprises receive investment support for technological innovation; $\mathrm{R} \& \mathrm{D}$ support is largely driven by selfemployment and service purchases. For seafood enterprises, the level of technology of seafood processing and exporting enterprises is just above average. As for electronics enterprises, technology and equipment of domestic enterprises is 10-20 years backward compared to the region and the world [12]. The weakness of technology has made the production capacity of Vietnamese enterprises unable to meet the requirements of large corporations in the world.

In addition, the management capacity of enterprises also has many points to complete. In Vietnamese enterprises, innovation, improvement, creation activities have not been paid enough attention. Limited technological capacity makes it difficult for Vietnamese enterprises to compete on price and quality. Vietnamese enterprises, if they are involved in the global value chain, assume the position of creating less value added.

The Korean case study shows that thanks to the early development of education and a large investment in science and technology, the country quickly built a highly independent economy, sufficient capacity to shift the economy from low value-added industries to high value-added industries. As the economy grows, the advantages of labor and capital will disappear, at this time high quality human resources along with technological advances will be factors that enhance the competitiveness of the background economy and promote sustainable growth. The highlight of Korea's education and science and technology policy making is that the government uses a practical approach and step by step in each stage of economic development and this has shown high efficiency. The step-by-step approach here is demonstrated by the government's creation and upgrading of infrastructure in the early years; then its aim to improve the quality of education and promote innovation. Through Korea's development, it can also be seen that education 
and economic growth have a mutual relationship and promote each other. Education helps create a knowledgeable workforce, thereby increasing labor productivity and paving the way for economic growth [13]. In contrast, the more developed the economy is, the more highly qualified workforce it requires to acquire and apply new knowledge, new techniques, thereby promoting education development.

Hence, the investment in education and innovation should be the top priority of the government and should not be delayed. The government should encourage and coordinate with the private sector to invest more and more effectively in these areas. Educational and science and technology policies should be tied together and linked to the country's economic development strategy.

\subsection{Utilize Invested Capital}

The infrastructure system determines the development of an economy because it provides the conditions for the activities of the economy to take place. Therefore, focusing on infrastructure development is always one of the important requirements in the economic development of any country [14]. In Vietnam, despite over 35 years of renovation, the infrastructure is still backward. This can be clearly seen through the interrupted highway system that many localities have only one type of access road, the status of reconstructed road degradation occurs on a regular basis, the backward railway system, inadequate transport of electricity, lack of clean water, and urban traffic congestion is quite bad. The clear evidence shows that as long as the infrastructure is not modernized and synchronized, Vietnam can hardly break through. The role of investment capital in economic growth is undeniable. However, how to use it to bring the best effect, to avoid wasting resources is not something every country can do.

The experience of Korea shows that the implementation of austerity policy to increase the savings rate, even the sacrifice of social welfare, is sometimes necessary to provide capital for development in the early periods. In particular, the investment should be focused, avoiding spreading and adjusting according to the nation's economic strategy. The government should make the most of its capital and allocate it to prioritized sectors and sectors, monitor activities and promote businesses to achieve their goals. Vietnam cannot wait for aid and loans but creating new forms of investment, initially with BOT, PPP, among others. In addition to the above changes, according to William Pesek - General Director of Bloomberg in Vietnam, the completion of financial institutions, through the formation of capital market development, plays an important role in developing the economy to escape the middle income trap. Over the past few years, Vietnam's growth has been quite high, but the economy mainly relies on investment capital from banks, while other channels in the capital market such as stocks and bonds are still slow to develop. Credit growth in developing countries is usually only 0.6-0.7 times of GDP but in Vietnam it is 1.2 times of GDP [15], so it needs to be reduced together with the restructuring of the capital and money market.

\section{Conclusion}

South Korea's impressive rapid growth from a low-income country to a high-income country is an experience that developing countries can certainly learn from. Especially, the period 1960s - 1990s when South Korea extraordinarily escaped from the middle-income trap. Indeed, many former low-income countries that have transitioned to middle-income countries, have to some extent followed similar policies or growth patterns of South Korea. Many countries that have transitioned to middle-income status find themselves unable to move on to high-income status. In fact, out of the 110 middle-income countries from the 1960s, only 13 including South Korea, have transitioned to high-income status. 
After 10 years of development, Vietnamese per capita income increased from $\$ 1,371$ in 2010 to $\$ 2,715$ in 2020 , which is not adequate by potential and capability [16]. Vietnam can escape from the middle-income trap with not only high levels of efficient government system but also modern and productivity-enhanced industrialization. These are the areas that South Korea has certainly achieved and the ones that Vietnam can emulate. Considering the rather similar conditions between Vietnam and South Korea and the latter's initial economic development experience, this paper concludes that: i) Vietnam needs to focus on dealing with structural areas to utilize strength and reduce weaknesses by promoting advanced and exported agricultural products and industrial sectors; ii) The Government needs to enhance power and control over the macro policies with suitable supports for priority sectors as well as leading private firms; iii) Education, human resource and technology must be upgraded to meet the need of market demand for the long term development; and iv) Capital, which may come from both domestic and international sources, is also an important factor to achieve the target of becoming a high-income country. The above four groups of solution will be really effective if the Govrnment can work with private sectors to utilize the domestic power and strength.

\section{References}

[1] The World Bank, Classifying Countries by Income, https://datatopics.worldbank.org/worlddevelopment-indicators/stories/the-classificationof-countries-by-income.html (accessed on: April $\left.1^{\text {st }}, 2020\right)$.

[2] D. Kasenda, Can Asian Developing Countries Stuck In A "Middle-Income Trap" Learn From South Korea's Economic Development Experience?, GDN working paper No.86, Global Development Network (GDN), Washinton D. C, 2015.
[3] S. Aiyar, R. Duval, D. Puy, Y .Wu, L. Zhang, Growth Slowdowns and the Middle-Income Trap, IMF Working Paper 71, 2013.

[4] K. Ohno, The Middle-Income Trap: Implications for Industrialization Strategies in East Asia and Africa, Three Policy Discussion Papers, GRIPS Development Forum, 2009.

[5] K. S. Kim, Industrial Policy and Industrialisation in South Korea: 1961-1982 - Lessons on Industrial Policies for Other Developing Countries, Kellog Institute, Working Paper, No. 39, 1985.

[6] S. Chung, Innovation, Competitiveness and Growth: South Korean Experiences, Annual World Bank Conference on Development Economics, 2011.

[7] C. Harvie, H. H. Lee, Export Led Industrialisation and Growth - South Korea's Economic Miracle 1962-89, University of Wollongong, Economic Working Paper Series, 2003.

[8] T. V. Tho, The Middle-Income Trap: Issues for Members of the Association of Southeast Asian Nations, Asian Development Bank Institute Working Paper Series, 2013.

[9] The World Bank, How to avoid middle income traps, http://blogs.worldbank.org/developmenttalk /how-avoid-middle-incometraps/, 2013 (accessed on: April $\left.20^{\text {th }}, 2020\right)$.

[10] 2018 JETRO Survey on Business Conditions of Japanese Companies in Asia and Oceania, 2019.

[11] Ceicdata, Vietnam Labour Productivity Growth, https://www.ceicdata.com/en/indicator/vietnam/la bour-productivity-growth (accessed on: November $\left.3^{\text {rd }}, 2020\right)$.

[12] J. Felipe, A. Abdon and U. Kumar, Tracking the Middle-Income Trap: What is it, Who is in It and Why?, Working Paper No. 715, Levy Economics, Institute of Bard College, 2012.

[13] A. Flaaen, E. Ghani, S. Mishra, How to Avoid Middle Income Traps? Evidence from Malaysia, Policy Research Working Paper 6427, World Bank, 2013.

[14] I. Gill, H. Kharas, An East Asia Renaissance: Ideas for Economic Growth, World Bank, 2007.

[15] The Economist, The Middle-income Trap, http://www.economist.com/blogs/graphicdetail/2012 /03/focus-3/, 2012 (accessed on: April 20 $0^{\text {th }}, 2020$ ).

[16] World Bank National Accounts Data and OECD National Accounts Data files, https://data.worldbank.org/indicator/NY.GDP.PC AP.CD?locations $=\mathrm{VN}$ (accessed on: November $\left.3^{\text {rd }}, 2020\right)$. 